\title{
METHANOGENESIS AND SYNTHESIS OF VOLATILE FATTY ACIDS IN THE RUMEN OF COWS AND THEIR CHANGEABILITY UNDER THE INFLUENCE OF ENSILED PLANT ADDITIVES
}

\author{
Department of Biostructure and Animal Physiology, Wroclaw University of Environmental and Life \\ Sciences \\ ${ }^{1}$ Department of Cattle Breeding and Milk Production, Wroclaw University of Environmental and Life \\ Sciences
}

\begin{abstract}
The aim of the research was determining the influence of select silages used in cow breeding on the production of methane and volatile fatty acids in the rumen digesta in the in vitro study. The rumen digesta for the experiment were obtained from 10 Polish Holstein-Frisian cows of black and white variety with a probe. The sampled digesta were then diluted in buffer solution and homogenized. To prepare fermentation samples, the digesta were placed in serum bottles with $1 \mathrm{~g}$ of supplementary substrates: I - corn silage, II - grass silage. The bottles were then flushed in $\mathrm{CO}_{2}$ and in vitro fermentation was performed at $39^{\circ} \mathrm{C}$ for 8 and $24 \mathrm{~h}$. After the fermentation, the amount of fermentation gas was measured and the general concentration and profile of VFA were determined using a gas chromatograph (Agilent Technologies 7890A GC System). The research determined the influence of corn and grass silages on the production of methane in the cow rumen, the synthesis of VFA and the changeability of particular VFA fraction shares in the process of in vitro fermentation. The use of grass silage decreases methane production in the fermentation of rumen digesta. Corn silage used as a substrate in the fermentation of ruminal fluid increases propionate and butyrate production. The obtained results suggest that the use of grass silage reduces methane production in the rumen digesta of cows, but because of changes in the proportion of propionate and butyrate it is necessary to supplement the cow feed with grass silage as well.
\end{abstract}

Key words: methanogenesis, volatile fatty acids, silages, cows, in vitro fermentation.

\section{INTRODUCTION}

The global growth in the methane emission observed in the last few decades has had a negative influence on the environment. Higher methane concentration correlates with the population growth: $70 \%$ of methane production is man-made, the remaining $30 \%$ is attributed to natural sources (Schwietzke et al. 2016). Agricultural emissions of methane account for 205 to 245 million tons annually (Moss et al. 2000).

Ruminants are methane producers but its amount may be modified by appropriate nutrition (Benchaar et al. 2013). This modification is accompanied by changes in the profile of volatile fatty acids (VFA) which is closely connected with milk yield, its composition

Corresponding author: Ewa Pecka-Kiełb, Department of Biostructure and Animal Physiology, Wroclaw University of Environmental and Life Sciences, Norwida 31, 50-375 Wroclaw, Poland, e-mail: pecka.ewa@gmail.com, ORCID: 0000-0002-8703-826. 
and quality (Siciliano-Jones and Murphy 1989; Pecka-Kiełb et al. 2018). The VFA production in the cow rumen is influenced by appropriately balanced diet and feeding frequency (Chamberlain et al. 1983).

High global emission of methane and danger it creates initiate research into methods of reducing the phenomenon. Methane production in the process of fermentation of rumen digesta may be modified by feeding, for example grass silage. The profile of volatile fatty acids created in the process of fermentation is essential for the animal health. The aim of research into the rumen fermentation is not just reducing the methane emission by using silages, but also obtaining the desired VFA profile. Therefore it is essential to investigate the influence of select silage substrates used in cow nutrition on the levels of methane and volatile fatty acids production in the rumen digesta in the in vitro tests.

\section{MATERIAL AND METHODS}

\section{Animals and substrates used in the in vitro fermentation}

The experiment was conducted in the herd of Polish Holstein-Friesian cows of black and white variety. The animals were kept in the free stall housing system and fed TMR composed of: corn silage $4921.1 \mathrm{~g} / \mathrm{kg}$, alfalfa haylage $87.9 \mathrm{~g} / \mathrm{kg}$, hay $26.4 \mathrm{~g} / \mathrm{kg}$, alfalfa forage $290 \mathrm{~g} / \mathrm{kg}$, post-extraction rapeseed meal $35.1 \mathrm{~g} / \mathrm{kg}$, barley $26.4 \mathrm{~g} / \mathrm{kg}$, lupin $17.6 \mathrm{~g} / \mathrm{kg}$, triticale $17.6 \mathrm{~g} / \mathrm{kg}$, and vitamins for lactating cows $7.0 \mathrm{~g} / \mathrm{kg}$.

The selection of animals for the experiment was based on age and milk yield in the previous lactation. Cows selected for the experiment were in the second or third lactation with average milk yield of $8500 \mathrm{~L}$ in the previous laction. Feed ration was composed according to the French INRA norm (IZ-INRA 2009).

The probe was used to collect samples of rumen digesta from 10 cows 2 hours after the morning feeding with the TMR. Corn and grass silages were then added as fermentation substrates. Grass was harvested using a forage harvester in the ear emergence stage while corn was in the dough stage. 40 tons of forage was then ensiled on a concrete floor without silage additives.

\section{In vitro fermentation}

The rumen digesta were mixed with the buffer solution (McDougall 1948) in the $1: 3$ ratio and homogenized. The $\mathrm{pH}$ of the obtained suspension was measured using a $\mathrm{CP}-401 \mathrm{pH}-$ -metre (Elmetron, Poland) with an EPP-3 electrode and a temperature sensor. The samples containing $80 \mathrm{ml}$ of homogenized digesta were put in $125 \mathrm{ml}$ serum bottles (Sigma-Aldrich) and $1 \mathrm{~g}$ of substrates added. The bottles were flushed in carbon dioxide from a pressure bottle and sealed tightly using a capping machine. The samples were the incubated in a shaking water bath at $39^{\circ} \mathrm{C}$ for 8 and $24 \mathrm{~h}$.

\section{Analysis of select fermentation products}

After the incubation, the headspace pressure created by the fermentation gases in the serum bottles was measured. Methane content in the gases was then measured using a gas chromatograph (Agilent Technologies 7890A GC System) with a thermal conductivity detector (TDC) and a flame ionisation detector (FID). 
The $\mathrm{pH}$ value in the liquid digesta samples was determined. The samples were then centrifuged $(2800 \mathrm{~g}$ for $20 \mathrm{~min}$ ) and formic acid was added $(0.1 \mathrm{ml} / 2 \mathrm{ml}$ solution) to stop the fermentation processes. Gas chromatograph with a FID and the Agilent J\&W column DB-WAX, with helium as the carrier gas (flow: $25 \mathrm{ml} / \mathrm{min}$ ) was used to determine the total concentration and the proportions of particular VFAs: acetate, propionate, isobutyrate, butyrate, isovalerate, valerate and caproate. Their identification and concentration in the analyzed samples was performed by comparing retention time and the peak area with the Sulpeco standard using ChemStation software.

\section{Calculations and statistical analysis}

Based on the results of the level and profile of volatile fatty acids analysis, the proportions of acetate to propionate and butyrate were calculated.

The results were analyzed using two-factor analysis of variance ANOVA in the Statistica 10.0 programme (StatSoft Polska, Kraków, Poland). The $\mathrm{P}<0.05$ and $\mathrm{P}<0.01$ significance was declared.

\section{RESULTS AND DISCUSSION}

The type of food, the frequency of meals and the fermentation time determine the dynamics of microbial fermentation in the rumen of cows causing an increase or a decrease of gas production and VFA synthesis (Chamberlain et al. 2002).

Research into the reduction of methane produced by ruminants through the use of different diets and dry as well as ensiled plant substrates has been carried out since the beginning of the 20th century. The results suggest that within last decades the amount of methane produced in the cow digestive tract has fallen by $30 \%$ (Johnson and Johnson 1995).

The present experiment showed the influence of corn silage (I) and grass silage (II) on gas production in the in vitro fermentation of cow rumen digesta (Table1). Both in the 8- and 24-hour fermentation, the total gas production - including methane - was reduced due to the grass silage (II) substrate. In their research, Beauchemin et al. (2008) observed a similar relation: feeding corn silage to animals increases methane emission in the rumen as compared to feeding grass silage. Grass silage has a positive influence on microbial fermentation in the rumen reducing gas emission, and thus increasing milk yield (Benchaar et al. 2013). Fermentation time also influences methanogenesis in the cow rumen (Beauchemin et al. 2008). In cows and in sheep, the longer the fermentation time, the greater gas production including methane - in the rumen (Miśta et al. 2014; Pecka-Kiełb et al. 2015). In the 8-hour fermentation in vitro.

Under the influence of corn silage, in the 8-hour in vitro fermentation 20.509 [mmol $\cdot \mathrm{I}^{-1}$ ] of methane was recorded, while in the 24- hour of this process, the methane emission level increased by about $50 \%$. The results of the present research correspond to the literature data. 
Table 1. The influence of plant silage additives and fermentation time on gas emission in the rumen digesta of cows in the in vitro fermentation

\begin{tabular}{|c|c|c|c|c|c|c|c|}
\hline \multirow{2}{*}{ Fermentation } & \multirow{2}{*}{$\begin{array}{c}\text { Time } \\
{[\mathrm{h}]}\end{array}$} & \multicolumn{2}{|c|}{ Substrates } & \multirow{2}{*}{ SEM } & \multicolumn{3}{|c|}{$P$ value } \\
\hline & & I & II & & $S$ & $\mathrm{~h}$ & $S \times h$ \\
\hline \multirow{2}{*}{$\begin{array}{l}\text { Methane } \\
{\left[\mathrm{mmol} \cdot \mathrm{dm}^{-3}\right]}\end{array}$} & 8 & 20.509 & 15.479 & \multirow{2}{*}{1.646} & \multirow{2}{*}{0.110} & \multirow{2}{*}{0.006} & \multirow{2}{*}{0.963} \\
\hline & 24 & 29.158 & 24.405 & & & & \\
\hline \multirow{2}{*}{$\begin{array}{l}\text { Gas production } \\
{\left[\mathrm{mmol} \cdot \mathrm{dm}^{-3}\right]}\end{array}$} & 8 & 131.608 & 123.159 & \multirow{2}{*}{3.038} & \multirow{2}{*}{0.209} & \multirow{2}{*}{0.000} & \multirow{2}{*}{0.611} \\
\hline & 24 & 153.625 & 150.005 & & & & \\
\hline
\end{tabular}

$\mathrm{S}$ - influence of substrate, $\mathrm{h}$ - influence of time, $\mathrm{S} \times \mathrm{h}$ - influence of substrate and time.

SEM - standard error of the mean.

I - corn silage.

II - grass silage.

Corn and grass silages have different chemical compositions: grass silage usually has higher content of non-structural carbohydrates (NSC) (Hildebrand et al. 2010). Both corn and grass silages increase the production of VFA in the cow rumen, but grass silage (II) causes a bigger growth of VFA synthesis than corn silage (I) (Contreras-Govea et al. 2011). At the 24th hour of in vitro fermentation, a higher concentration of the total VFA pool was noted under the influence of grass silage (II) $\left(512.645 \mathrm{mmol} \cdot \mathrm{I}^{-1}\right)$, while at the 8 th hour of this process a higher VFA level $\left(338.387 \mathrm{mmol} \cdot \mathrm{I}^{-1}\right)$ was noted after applying corn silage (I). Therefore, it can be concluded that the fermentation time of the substart has a significant role in the synthesis of VFA in the rumen of cows (Table 2). The experiment results correspond to the literature data.

Table 2. The influence of ensiled plant substrates and fermentation time on the concentration and profile of volatile fatty acids $\left[\mathrm{mmol} \cdot \mathrm{dm}^{-3}\right]$ in the rumen digesta of cows

\begin{tabular}{|c|c|c|c|c|c|c|c|}
\hline \multirow[t]{2}{*}{ Fermentation } & \multirow{2}{*}{$\begin{array}{c}\text { Time } \\
{[\mathrm{h}]}\end{array}$} & \multicolumn{2}{|c|}{ Substrates } & \multirow{2}{*}{ SEM } & \multicolumn{3}{|c|}{$P$ value } \\
\hline & & I & II & & $S$ & $\mathrm{~h}$ & $S \times h$ \\
\hline \multirow[t]{2}{*}{ Total VFA } & 8 & 338.387 & 278.168 & \multirow{2}{*}{4.320} & \multirow{2}{*}{0.585} & \multirow{2}{*}{0.000} & \multirow{2}{*}{0.112} \\
\hline & 24 & 481.371 & 512.645 & & & & \\
\hline \multicolumn{8}{|l|}{ VFA } \\
\hline \multirow[t]{2}{*}{ Acetate } & 8 & 222.160 & 180.320 & \multirow{2}{*}{15.780} & \multirow{2}{*}{0.940} & \multirow{2}{*}{0.000} & \multirow{2}{*}{0.078} \\
\hline & 24 & 305.001 & 350.493 & & & & \\
\hline \multirow[t]{2}{*}{ Propionate } & 8 & 64.676 & 57.450 & \multirow{2}{*}{4.010} & \multirow{2}{*}{0.116} & \multirow{2}{*}{0.000} & \multirow{2}{*}{0.795} \\
\hline & 24 & 103.170 & 95.810 & & & & \\
\hline \multirow[t]{2}{*}{ Isobutyrate } & 8 & 2.042 & 1.837 & \multirow{2}{*}{0.170} & \multirow{2}{*}{0.890} & \multirow{2}{*}{0.000} & \multirow{2}{*}{0.352} \\
\hline & 24 & 3.196 & 3.473 & & & & \\
\hline \multirow[t]{2}{*}{ Butyrate } & 8 & 39.187 & 30.111 & \multirow{2}{*}{2.200} & \multirow{2}{*}{0.440} & \multirow{2}{*}{0.000} & \multirow{2}{*}{0.640} \\
\hline & 24 & 53.223 & 47.492 & & & & \\
\hline \multirow[t]{2}{*}{ Isovalerate } & 8 & 3.669 & 3.166 & \multirow{2}{*}{0.320} & \multirow{2}{*}{0.579} & \multirow{2}{*}{0.000} & \multirow{2}{*}{0.658} \\
\hline & 24 & 6.123 & 6.066 & & & & \\
\hline Valerate & 8 & 4.609 & 3.800 & 0100 & O 540 & חمת م & 0760 \\
\hline & 24 & 7.191 & 6.924 & 0.490 & 0.540 & 0.000 & 0.102 \\
\hline Caproate & 8 & 2.044 & 1.487 & חמ ח ח & م210 & $\cap \cap \cap 1$ & 0446 \\
\hline & 24 & 3.467 & 2.391 & 0.200 & 0.210 & 0.001 & 0.446 \\
\hline
\end{tabular}

Explanations see Table 1. 
In the research conducted by Contreras-Govea et al. (2011), it was demonstrated that the use of grass silage - as compared to corn silage - increases the levels of acetate, propionate and valerate in the rumen digesta. In our research, the addition of grass silage (II) increased the concentration of acetate and isobutyrate. Higher levels of propionate, butyrate and isovalerate after 8 and $24 \mathrm{~h}$ of in vitro fermentation were observed when corn silage (I) was added In the experiment carried out by Van Gastelen et al. (2015), the addition of the same substrate (I) increased the concentration of butyrate and isovalerate. Our results correspond to the results obtained by other authors.

The ratio of acetate, to propionate and butyrate is estimated at $6: 3: 1$. Their proportions are largely influenced by feed ration supplied to animals. Feeding large amounts of hay causes disturbance in the synthesis of VFA in the cow rumen and increases the concentration of acetate; greater share of cereal-based feeds increases the concentration of propionate to $40-50 \%$ (Van Gastelen et al. 2015).

Chamberlain et al. (2002) suggest in their research that the use of plant silages in cow nutrition changes the synthesis of VFA in the cow rumen by reducing the concentration of acetate and raising the concentration of propionate and butyrate in the fermentation process. However, the type of silage used also has some influence on the concentration of these three volatile fatty acids.

According to Contreras-Govea et al. (2011), corn silage, unlike grass silage, changes the proportions of acetate synthesis reducing its concentration and increasing the concentration of propionate and butyrate in the rumen. A similar relation was observed in our research: both in in the 8th and the 24th hour of the in vitro fermentation the acetate to propionate ratio was more favourable in the samples containing corn silage (I) than in the samples with grass silage (II) (Fig. 1, 2).

I

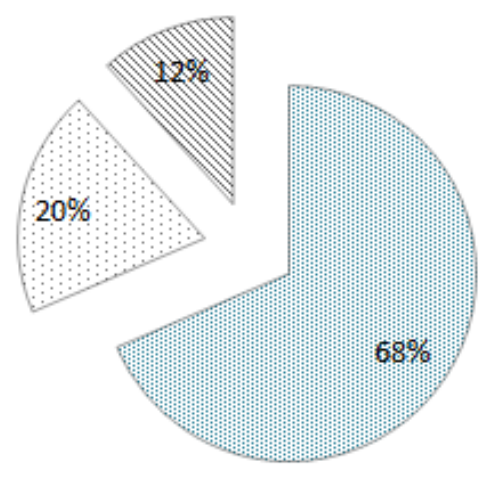

II

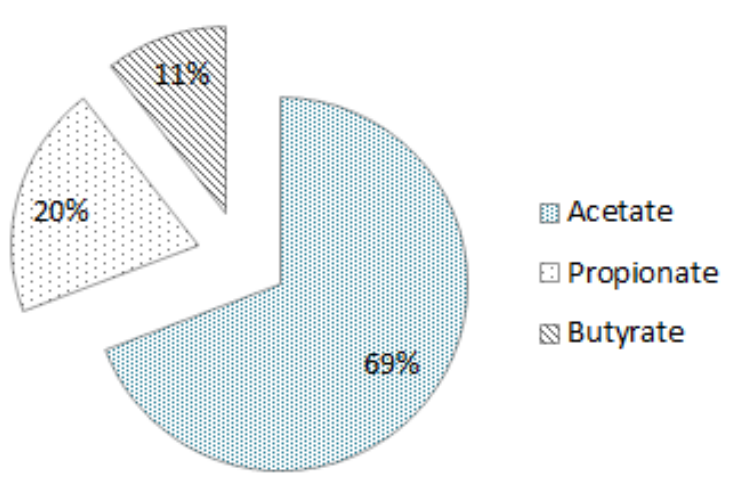

Fig. 1. The influence of corn silage (I), grass silage (II) and fermentation time ( $8 \mathrm{~h}$ ) on the proportions of acetate, propionate and butyrate 
।

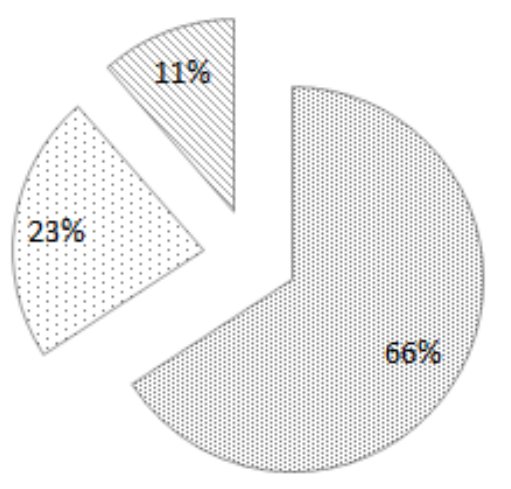

II

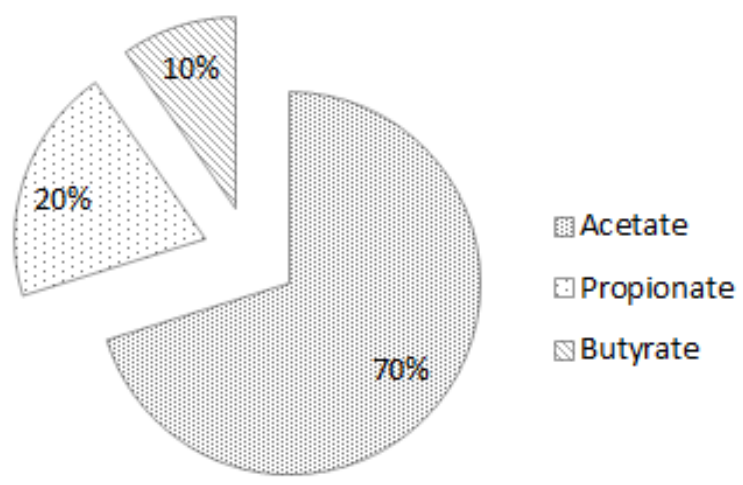

Fig. 2. The influence of corn silage (I), grass silage (II) and fermentation time (24 h) on the proportions of acetate, propionate and butyrate

The value of $\mathrm{pH}$ is an important parameter determining microbial activity in the rumen, and - as a result - the fermentation process. The best conditions for fermentation exist with $\mathrm{pH}$ between 6.2 and 6.6 (Veth and Kolver 2001). When $\mathrm{pH}$ of the rumen digesta is lower, the level of VFA synthesis decreases (Bhatta et al. 2006). In our research, rumen pH was between 6.34 and 6.61 and no significant differences between group I and group II were observed (Fig. 3), but the $\mathrm{pH}$ value in the $8^{\text {th }}$ hour of in vitro fermentation was much lower than in the 24th hour. These results are similar to those obtained by other authors, who also observed the fall in $\mathrm{pH}$ with longer fermentation time (Miśta et al. 2014).

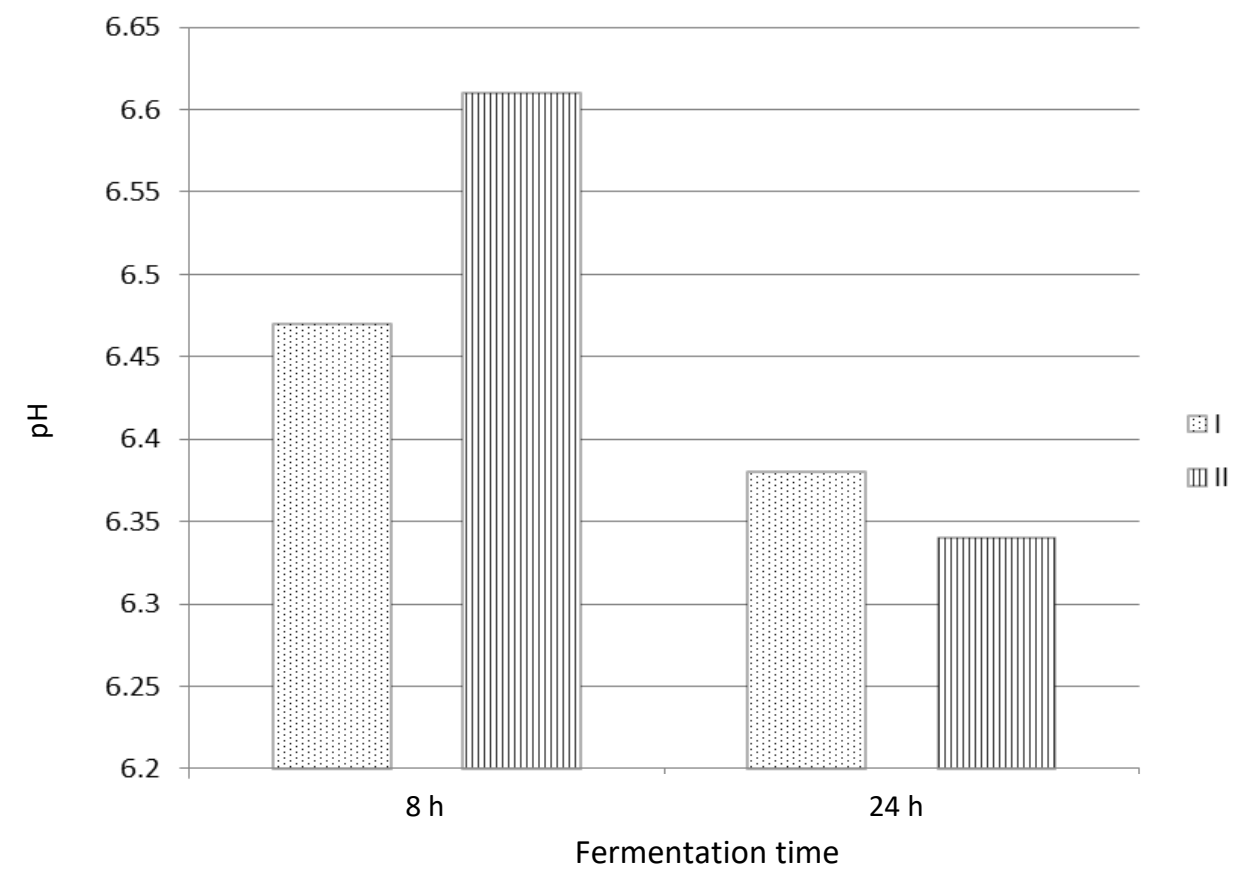

Fig. 3. The influence of corn silage (I), grass silage (II) and fermentation time on $\mathrm{pH}$ of the rumen digesta in the in vitro fermentation process 


\section{CONCLUSIONS}

Silages used in the research influence the macrobial fermentation profile in the cow rumen.

Grass silage used as substrate in the in vitro fermentation of rumen digesta of cows causes a decrease in methane emission.

Corn silage used as substrate in the in vitro fermentation of rumen digesta of cows increases the production of propionate and butyrate.

The results obtained in this experiment confirm the possibility of reducing methane emission in the process of ruminal fermentation by supplying grass silage in the feed ration. However, because it decreases the production of propionate and butyrate in the process of fermentation, it is necessary to use also corn silage in cow nutrition.

\section{REFERENCES}

Beauchemin K.A., Kreuzer M., O'Mara F., McAllister T.A. 2008. Nutritional management for enteric methane abatement. A review. Aust. J. Exp. Agric. 48(2), 21.

Benchaar C., Hassanat F., Gervais R., Chouinard P.Y., Julien C., Petit H.V., Massé D.I. 2013. Effects of increasing amounts of corn dried distillers grains with solubles in dairy cow diets on methane production, ruminal fermentation, digestion, $\mathrm{N}$ balance, and milk production. J. Dairy Sci. 96(4), 2413-2427.

Bhatta R., Tajima K., Kurihara M. 2006. Influence of temperature and pH on fermentation pattern and methane production in the rumen simulating fermenter (RUSITEC). Asian-Australas. J. Anim. Sci. 19, 376-380.

Chamberlain D.G., Thomas P.C., Anderson F.J. 2002. Volatile fatty acid proportions and lactic acid metabolism in the rumen in sheep and cattle receiving silage diets. J. Agric. Sci. 101(01), 47.

Contreras-Govea F.E., Muck R.E., Mertens D.R., Weimer P.J. 2011. Microbial inoculant effects on silage and in vitro ruminal fermentation, and microbial biomass estimation for alfalfa, bmr corn, and corn silages. Anim. Feed Sci. Technol. 163(1), 2-10.

Hildebrand B., Boguhn J., Rodehutscord M. 2010. Effect of maize silage to grass silage ratio and feed particle size on ruminal fermentation in vitro. Animal. 5(04), 528-536.

IZ PIB-INRA. 2009. Normy żywienia bydła, w: Normy żywienia przeżuwaczy. Wartość pokarmowa francuskich i krajowych pasz dla przeżuwaczy. Kraków, IZ PIB, 21-81. [in Polish].

Johnson K.A., Johnson D.E. 1995. Methane emissions from cattle. J. Animal. Sci. 73(8), 2483-2492.

McDougall E.I. 1948. Studies on ruminant saliva. 1. The composition and output of sheep's saliva. Biochem. J. 43, 99-109.

Miśta D., Pecka E., Zachwieja A., Zawadzki W., Bodarski R., Paczyńska K., Tumanowicz J., Kupczyński R., Adamski M. 2014. In vitro ruminal fluid fermentation as influenced by corn-derived dried distillers' grains with solubles. Folia Biol. 62(4), 345-351.

Moss A.R., Jouany J.P., Newbold J. 2000. Methane production by ruminants: its contribution to global warming. Ann. Zootech. 49(3), 231-253.

Pecka-Kiełb E., Zawadzki W., Zachwieja A., Michel O., Mazur M., Miśta D. 2015. In vitro study of the effect of corn dried distillers grains with solubles on rumen fermentation in sheep. Pol. J. Vet. Sci. 18(4), 751-758.

Pecka-Kiełb E., Zachwieja A., Wojtas E., Zawadzki W. 2018. Influence of nutrition on the quality of colostrum and milk of ruminants. Mljekarstvo 68(3), 169-181.

Schwietzke S., Sherwood O.A., Bruhwiler L.M.P., Miller J.B., Etiope G., Dlugokencky E.J., Michel S.E., Arling V.A., Vaughn B.H., White J.W.C., Tans P.P. 2016. Upward revision of global fossil fuel methane emissions based on isotope database. Nature 538(7623), 88-91. 
Siciliano-Jones J., Murphy M.R. 1989. Production of volatile fatty acids in the rumen and cecumcolon of steers as affected by forage: Concentrate and forage physical form. J. Dairy Sci. 72(2), 485-492.

Van Gastelen S., Antunes-Fernandes E.C., Hettinga K.A., Klop G., Alferink S.J.J., Hendriks W.H., Dijkstra J. 2015. Enteric methane production, rumen volatile fatty acid concentrations, and milk fatty acid composition in lactating Holstein-Friesian cows fed grass silage- or corn silage-based diets. J. Dairy Sci. 98(3), 1915-1927.

Veth M.J., Kolver E.S. 2001. Digestion of ryegrass pasture in response to change in $\mathrm{pH}$ in continuous culture. J. Animal Sci. 84(6), 1449-1457.

\title{
METANOGENEZA I SYNTEZA LOTNYCH KWASÓW TKUSZCZOWYCH W ŻWACZU KRÓW ORAZ ZMIENNOŚĆ TYCH PROCESÓW POD WPŁYWEM ZAKISZANYCH DODATKÓW ROŚLINNYCH
}

\begin{abstract}
Streszczenie. Przeprowadzone badania miały na celu określenie wpływu wybranych kiszonek stosowanych w żywieniu krów na poziom produkcji metanu oraz lotnych kwasów tłuszczowych $\mathrm{w}$ treści żwacza $\mathrm{w}$ warunkach in vitro. Materiał do badań stanowiła treść żwacza pobrana za pomocą sondy od 10 krów rasy polskiej holsztyńsko-fryzyjskiej, odmiany czarno-białej. Po pobraniu treść żwacza wymieszano $z$ buforem i poddano homogenizacji. W celu przygotowania próbek do fermentacji zhomogenizowaną treść odmierzono do buteleczek „serum bottles” i dodano $1 \mathrm{~g}$ uzyskanych substratów: I - kiszonka z kukurydzy, II - kiszonka $\mathrm{z}$ traw. Buteleczki wysycono $\mathrm{CO}_{2}$ i poddano 8- i 24-godzinnej fermentacji in vitro w wytrząsarce $\mathrm{z}$ łaźnią wodną, $w$ temperaturze $39^{\circ} \mathrm{C}$. Po inkubacji dokonano analizy wytworzonego gazu oraz oznaczono ogólne stężenie lotnych kwasów tłuszczowych (LKT) oraz udział poszczególnych frakcji. Wyniki zostały opracowane statystycznie przy użyciu chromatografu gazowego (Agilent Technologies 7890A GC System). W badaniach własnych stwierdzono wpływ zastosowania kiszonki z kukurydzy i kiszonki z traw na emisję metanu w treści żwacza krów oraz syntezę lotnych kwasów łłuszczowych (LKT), a także zmienność udziału procentowego poszczególnych frakcji LKT w procesie fermentacji in vitro. Zastosowanie kiszonki z traw obniża produkcję metanu w procesie fermentacji w treści żwacza krów. Natomiast kukurydza w formie kiszonki, stosowana jako substrat $w$ fermentacji płynu żwacza, wpływa na wzrost produkcji kwasu propionowego oraz masłowego. Uzyskane rezultaty wskazują na możliwość stosowania kiszonki z traw w celu obniżenia emisji metanu w treści żwacza krów, jednak ze względu na zmianę udziału kwasów propionowego i masłowego niezbędne jest stosowanie $w$ żywieniu krów, oprócz kiszonek z traw, również kiszonek z kukurydzy.
\end{abstract}

Słowa kluczowe: metanogeneza, lotne kwasy tłuszczowe, kiszonki, krowy, fermentacja in vitro. 